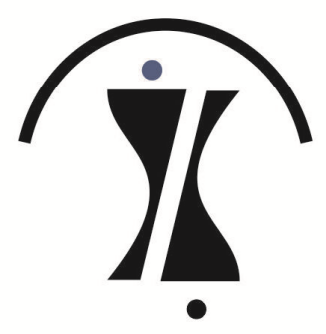

P R O B L E M S OF MANAGEMENT $\mathrm{IN} \bullet \mathrm{THE} 21 \mathrm{st}$ C E N T U R Y

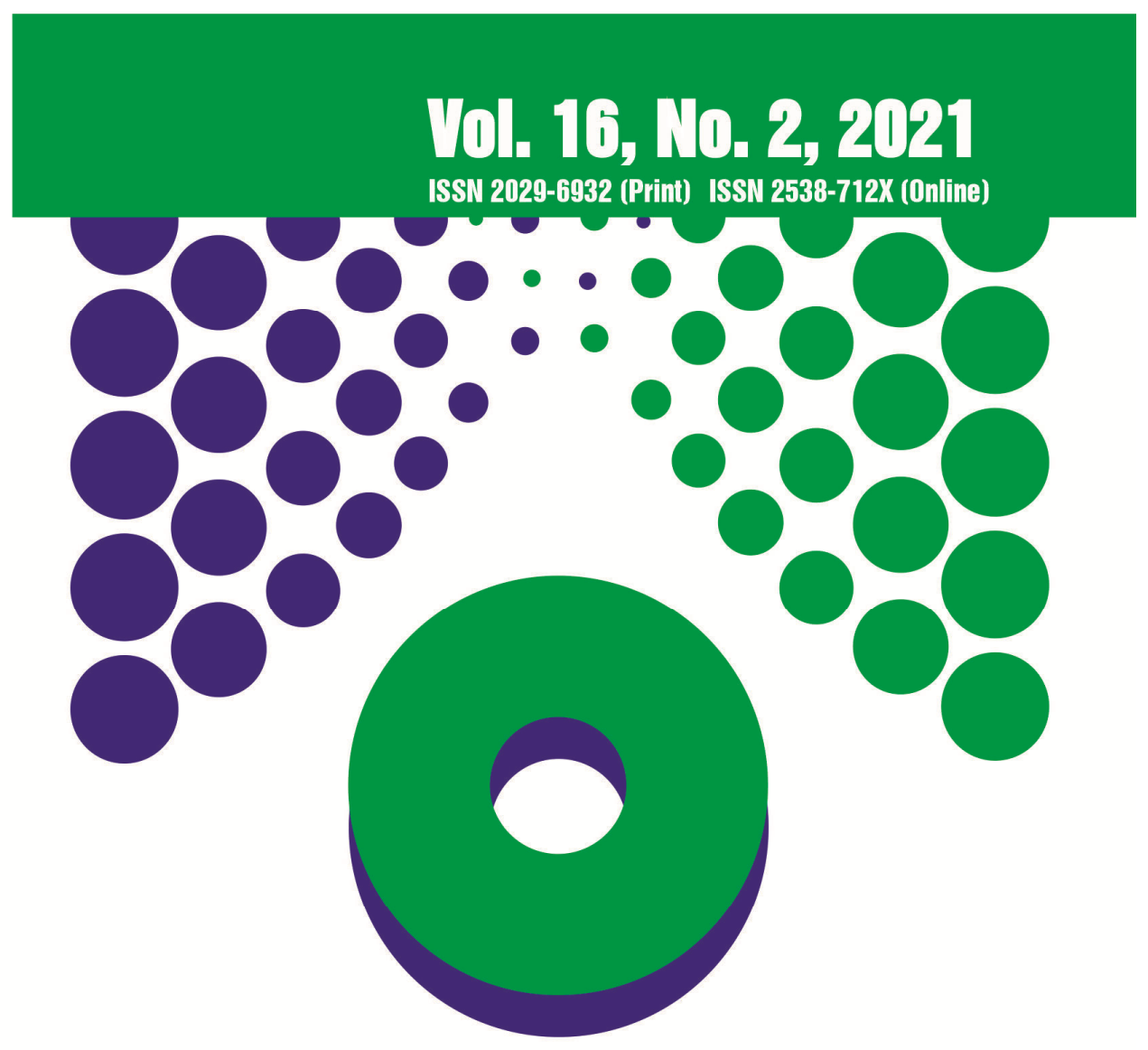

\title{
Problems of Management in the 21st Bentury
}




\section{PROBLEMS OF MANAGEMENT IN THE 21 ${ }^{\text {ST }}$ CENTURY}

Scientia Socialis Ltd. \& SMC „Scientia Educologica“, Lithuania, The Associated Member of Lithuanian Scientific Society, the Association of Lithuanian Serials, ESHS (European Society for the History of Science), and ICASE (International Council of Associations for Science Education)

The articles appearing in this scientific journal are indexed, listed and abstracted in:

Index Copernicus

EBSCO: Business Source Complete

EBSCO: Business Source Elite

EBSCO: Business Source Corporate

Contemporary Science Association/AAP databases TOC Premier (EBSCO list)

The Wroblewski Library of the Lithuanian Academy of Sciences

PECOB (Portal on Central Eastern and Balkan Europe)

Genamics JournalSeek

Ulrich's Periodicals Directory / Global Serials Directory

Zeitschriftendatenbank (ZDB)

Sjournals Index

ABI/INFORM (ProQuest)

ECONBIZ

EuroPub
Open Academic Journals Index (OAJI)

Scientific Indexing Services (SIS)

Scholar Steer

CNKI (China National Knowledge Infrastructure)

Scholar

Eurasian Scientific Journal Index (ESJI)

Information Matrix for the Analysis of Journals (MIAR)

Directory of Open Access Scholarly Resources (ROAD)

Academic Resource Index (ResearchBib)

World Catalogue of Scientific Journals (WCOJS)

Crossref

DOI

ResearchGate

ScienceGate

SCRIBD 
PROBLEMS

OF MANAGEMENT

IN THE $21^{\text {st }}$ CENTURY Vol. 16 , No. 2, 202

\section{Publisher}

Scientia Socialis, Ltd. in cooperation with SMC „Scientia Educologica“, Lithuania, the Associated Member of Lithuanian Scientific Society, the Association of Lithuanian Serials, European Society for the History of Science (ESHS) and International Council of Associations for Science Education (ICASE)

\section{Editor-in-Chief}

Prof. Dr. Vincentas Lamanauskas, Vilnius University, Lithuania

\section{Deputy Editor-in-Chief}

Dr. Iwona Gorzeń-Mitka, Czestochowa University of Technology, Poland

\section{Editorial Board}

Prof., dr. Aldona Andrzejczak, University of Economics and Business, Poland Prof., dr. Constantin Bratianu, Academy of Economic Studies, Bucharest, Romania Dr. Luca Bussotti, International Studies Center of ISCTE, Portugal Dr. Camille Carbonnaux, University of Lille Nord de France, France Assoc. prof., dr. Tsai-Hsin Chu, National Chiayi University, Taiwan Assoc. prof., dr. Dana Egerova, University of West Bohemia, Czech Republic Dr. Jorge Lima de Magalhães, Oswaldo Cruz Foundation/FIOCRUZ, Brazil Assoc. Prof., Dr. Vitalii Nitsenko, Odessa I.I.Mechnikov National University, Ukraine Dr. Jerzy Kaźmierczyk, Poznan University of Economics, Poland Prof., dr. Ivars Muzis, University of Latvia, Latvia Asst. prof., dr. Ivona Orzea, Academy of Economic Studies, Bucharest, Romania Dr. Ioan Constantin Dima, ,Valahia” University of Targoviste, Romania Prof., dr. Sonia Teresinha de Sousa Penin, University of Sao Paulo, Brazil Asst. prof., dr. Nikhil Chandra Shil, American International University, Dhaka, Bangladesh Assoc. prof., dr. Michelberger Pál, Óbuda University, Hungary Dr. Michal Kubenka, University of Pardubice, Czech Republic

Copyright of this issue is the property of Scientia Socialis Ltd. Lithuania. By virtue of their appearance in this open access journal, articles are free to use, with proper attribution, in educational and other non-commercial settings.

Index Copernicus (ICTM Value): 94.05 (2020).

CGIJ OAJI: 0.201 (2020)

Problems of Management in the 21st Century is an international, periodical, peer reviewed scientific journal, issued by the Scientia Socialis, Ltd. in cooperation with SMC „Scientia Educologica“.

Address: Scientia Socialis, Ltd.

Donelaičio Street 29, LT-78115 Siauliai, Lithuania

E-mail: problemsofmanagement@gmail.com

Phone: +370 687 95668; Skype: scientia12

Webpages: http://www.scientiasocialis.lt/pme/

ISSN 2029-6932 (Print) ISSN 2538-712X (Online) C Scientia Socialis Ltd., Lithuania, 2021 